\title{
Influence of Principals' Instructional Leadership on Science Teaching Competency
}

\author{
Mohd Zaid Ismail1', Azlin Norhaini Mansor², Zanaton Iksan², Mohamed Yusoff Mohd Nor ${ }^{2}$ \\ ${ }^{1}$ SM. Sains Hulu Terengganu, Terengganu, Malaysia \\ ${ }^{2}$ Fakulti Pendidikan Universiti Kebangsaan Malaysia, Bangi, Malaysia \\ Email: zaid5157@gmail.com
}

How to cite this paper: Ismail, M. Z., Mansor, A. N., Iksan, Z., \& Nor, M. Y. M. (2018). Influence of Principals' Instructional Leadership on Science Teaching Competency. Creative Education, 9, 2234-2244. https://doi.org/10.4236/ce.2018.914164

Received: August 16, 2018

Accepted: October 26, 2018

Published: October 29, 2018

Copyright (c) 2018 by authors and Scientific Research Publishing Inc. This work is licensed under the Creative Commons Attribution International License (CC BY 4.0).

http://creativecommons.org/licenses/by/4.0/ (c) (i) Open Access

\begin{abstract}
Instructional leadership is a main aspect of principals' leadership in the school. The school's success, in turn, depends largely on principals' abilities in instructional leadership. Therefore, the purpose of this study was to identify principals' instructional leadership influence on science teaching competency. Using a quantitative approach, we surveyed instructional leadership and science teaching competency in 311 science teachers in Terengganu, Malaysia. The data were analyzed using structural equation modelling (SEM) by AMOS 22 and the results showed that all nine dimensions proposed for instructional leadership variables were significant with a loading factor of 0.70 0.84 . Correspondingly, the science teaching competency variables were significant too with a loading factor of $0.81-0.95$. Our findings indicated instructional leadership contributed significantly to the science teaching competency ( $\beta=0.51, \mathrm{CR}=8.589, \mathrm{p}=0.00$ ). In summary, we have successfully developed an interaction model between instructional leadership and science teaching competency.
\end{abstract}

\section{Keywords}

Instructional Leadership, Science Teaching Competency, Teaching and Learning, Science Teachers

\section{Introduction}

Leadership is the ability of an individual to influence people towards organisational goals. In the context of a school, the principal, as a school leader is a key to influencing teachers and staff in achieving academic excellence for all students. For this reason, an effective leader must have two qualities; first, the ability to influence his or her subordinates towards organisational goals (Khan et al., 2009), 
second, instructional leadership ability that encompasses teaching and student learning besides fulfilling their management duties (Blasé \& Blase, 2000; Quinn, 2002; Marks \& Printy, 2003; Day, Gu, \& Sammons, 2016).

Instructional leadership among school leaders is a key factor in the development of quality education and ultimately the school's success. International studies show when school leaders focus on instructional leadership, students' achievement improved by 20\% (Ministry of Education, 2013). Hence, mastery of instructional leadership by school principals is crucial for the school's success. In fact, the Malaysian Development Plan (PPPM) encouraged all school management staff including senior assistant teachers and senior subject teachers to be proficient in instructional leadership.

The concept of instructional leadership was clearly defined by Hallinger \& Murphy (1987) that involves three dimensions; defining school goals, managing teaching programs and promoting the school learning climate. Each dimension has specific functions such as coordinating curriculum, monitoring student progress, framing clear school goals, communicating clear school goals, protecting instructional time, promoting professional development, maintaining high visibility, providing incentives for teacher and students.

Besides instructional leadership, another factor that affects students' achievement is teaching competency. Generally, teaching competency consists of three aspects; knowledge, skills and value. However, Kunter, Klusmann, Baumert, Richter, Voss, \& Hachfeld (2013) gave a broader definition of teaching competency which includes teachers' pedagogical content knowledge, professional beliefs, work-related motivation and self-regulation. In Malaysia, teaching competency is included in a document called Malaysian Teacher Standard Document and are divided into three areas; 1) knowledge and understanding, 2) teaching and learning skills and 3) teachers professional development practices.

\section{Issue and Problem}

The success of a school depends largely on effective instructional leadership (Mattar, Pansiri, Heck, Shatzer, Caldarella, Hallam, Brown et al., 2013). However, most school principals in Malaysia do not carry out the instructional leadership functions as suggested by the instructional leadership experts. The reason for this, in reality, is, most principals do not give much emphasis on teachers teaching competencies but rather the focus is more on administrative duties (Mansor, 2006). Also, most instructional leadership models come from western education environments, particularly in the USA and European countries (Hallinger, 2005; Hallinger, 2009; Leithwood, Harris, \& Hopkins, 2008; Hallinger, Wang, Chen, \& Li, 2015). However, the education environment in Malaysia is very different from these countries and adopting a western model may affect the teachers' teaching competency.

Currently, the teaching competency in Malaysia is worrying. The report from Ministry of Education (2013) showed 52\% of teachers in Malaysia are still at an 
expectation level, while $31 \%$ are at satisfied level and only $12 \%$ are good and excellent. The report also found that only $31 \%$ of the teaching and learning levels were satisfactory and nearly $5 \%$ were weak. In fact, the evaluation of Standard 4 on the quality of teaching and learning which include aspects of student engagement, pupils' learning, student work, teachers' planning and preparation, teaching method, communication skills, educational resources, evaluation and questioning techniques recorded a low satisfactory score of 30\% (Ministry of Education, 2013).

Hence, this research is done to determine instructional leadership influence descriptively and aims to identify the contribution of instructional leadership influence on science teaching competency. This research involves science teachers only as science is the main subject in the Malaysian education system.

\section{Literature Review}

Blasé \& Blasé (2000) gave a very broad definition of instructional leadership by dividing it into four areas. The areas discussed were regarding prescriptive models, a study on instructional leadership, studies on the direct effects of principals' behaviour on teacher and classroom teaching as well as direct impact assessment and indirect effects on student achievement. A teachers' perception survey on how principals promote teaching and learning in schools was empirically conducted and two themes emerged for effective instructional leadership. One was to talk with teachers to encourage reflection, and the other was to promote professional development among teachers.

Quinn (2002) agreed with Blasé \& Blasé (2000) with regards to the importance of principals' leadership behaviour. He found that principals' teaching leadership had a strong relationship with teachers' teaching practices. Hence, he defines instructional leadership as principals' behaviour which affects the practice of teaching and thus improves students' achievement. Consequently, the principal is a strong teaching leader and is responsible for guiding teachers using the latest teaching strategies, technology and equipment for effective teaching. As an effective leader, the principals can influence the teachers' teaching practices. However, providing teachers with the right resources and incentives allows them to focus entirely on students' learning.

On the other hand, the concept of leadership by Hallinger \& Murphy (1985) is seen as more thorough and clear compared to the concepts suggested by other scholars. Hallinger \& Murphy (1985) incorporate instructional elements into teaching as one of the dimensions of their instructional leadership model. According to Hallinger \& Murphy (1987), failure to define the concept of instructional leadership is the greatest obstacle of the principal to act as a powerful teaching force. Therefore, they gave a clearer definition to the instructional leadership concept that involves three key roles of instructional leadership; defining school goals, managing teaching programs and promoting school learning climate. Each dimension stated has some functions, for example, in the dimension 
for managing teaching program, it involves supervisory functions and assessing the teaching, coordinating the curriculum and monitoring student progress (Hallinger \& Murphy, 1987).

Nevertheless, teaching competencies are the main requisites in ensuring the success of a school, especially in the academic field. Teaching competency main concept is related to the mastery of knowledge and skills especially the pedagogy skills and positive attitude (Kunter, Klusmann, Baumert, Richter, Voss, \& Hachfeld, 2013; Liakopoulou, 2011; Bhargava \& Pathy, 2011; Mariani \& Ismail, 2013). The concept of teaching competency is not centred on the teacher only but is tied to students' achievement. Moreover, a competent teacher is one who benefits his or her students in terms of knowledge in regards to the subjects being taught (Sahin, 2011).

In Malaysia, teaching competency outlines are in the Teachers Standard Malaysia Document (SGM) issued by the Ministry of Education Malaysia. In the document, there are three standard components for Malaysian teachers: 1) knowledge and understanding 2) teaching and learning skills and 3) practice of professionalism in teaching (Guru, 2009). For the science teachers, the Master Plan of Science in Malaysia's Early Standards can be used as a guideline to improve their teaching competency (Nasri, 2010). Three important aspects proposed in producing quality science teachers are knowledge and understanding, teaching and learning skills, and practising of professionalism. Although these aspects are the same as those contained in the Teacher's Standard Document, they are specific for the science curriculum such as science process skills, manipulative skills, experimental skills, inquiry skills etc.

There are many studies conducted to examine the teaching competency. (Ibrahim \& Amin, 2014) conducted a study on the development of a leadership model on principals and teachers teaching competencies in Terengganu. $\mathrm{He}$ surveyed 481 teachers in 55 secondary schools in Terengganu. The findings showed that teaching leadership has a positive correlation with teaching competency. Likewise, the study of (Yusof \& Ibrahim, 2015) investigates the correlation between the virtual instructional leadership and teaching competency and found that virtual instructional leadership was the predictor variable to teaching competency. (Davarajoo, 2012) conducted a study on instructional leadership relationships with work commitment and job satisfaction of 172 teachers in 9 schools in the Kuala Selangor district primary school. He found that there was a significant relationship between instructional leadership and work commitment and teachers' job satisfaction.

Based on the literature, the study's conceptual framework is as in Figure 1 .

\section{Method}

The study used quantitative methods and adopted a survey approach that examines population by measuring data from a part of the sample (Airasian \& 
Instructional leadership

- Framing clear school goals

- Communicating clear school goals

- Coordinating curriculum

- Monitoring student progress

- Protecting instructional time

- Promoting professional development

- Maintaining high visibility

- Providing incentives for teachers

- Providing incentives for students

Figure 1. Conceptual framework.

Gay, 2003; Cohen, Manion, \& Morrison, 2007). The study's population was secondary school science teachers from all districts in Terengganu, Malaysia. The sample for the study consisted of 311 science teachers using stratified random sampling techniques and the sample size determination formula by Krejcie \& Morgan, 1970). We collected data using the Principles Instruction Management Rating Scales (PIMRS) questionnaire which was later modified by Mohd Yusri, 2012) for instructional leadership variables. The variable on science teaching competency questionnaire was a modification from Nasri (2010) questionnaire on the competency of science teachers.

The data were analysed using the Structural Equation Model (SEM) from the AMOS 22 program. The direct contribution of independent variables to dependent variables was determined using Critical Ratio (CR) values. When a CR value exceeds 1.96 and p-value $<0.05$, this indicates that the predictor variables contribute significantly to the dependent variables. Whereas, the corresponding hypothesis model tested is verified using the index fit $\chi$ (CMIN), GFI, CFI, RMSEA, PCFI and PNFI. The hypothesis model is considered matched to the data if the value of $\chi^{2}$ is not significant or exceeds 0.05 (Piaw, 2009; Meyers, Gamst, \& Guarino, 2006). RMSEA value is very good if smaller than 0.08 , but it is still accepted if less than 0.1 (Byrne, 1998) \& (Mohd Yusri, 2012). CFI value greater than 0.90 is accepted, but the CFI value between 0.80 and 0.89 is considered within the accepted margin (Knight, Virdin, Ocampo, \& Roosa, 1998). Fit index values PNFI and PCFI are accepted if it exceeds 0.50 (Meyers, Gamst, \& Guarino, 2006). The model is considered matched when the bootstrap value exceeds 0.05 (Bollen \& Stine, 1992). When the bootstrap value exceeds 0.5 , this indicates that there is no difference between the data collected from the respondents and the proposed model. Therefore, the proposed model is valid based on the data collected from the respondents.

\section{Results}

All variables are in normal distribution and correlated with each other. Table 1 shows the matrices for descriptive information, normality and correlation of the variables. 
Table 1. Descriptive, normality and correlation.

\begin{tabular}{|c|c|c|c|c|c|c|c|c|c|c|c|c|c|c|c|}
\hline Variables & $\mathbf{M}$ & SD & Skewness & Kurtosis & 1 & 2 & 3 & 4 & 5 & 6 & 7 & 8 & 9 & 10 & 11 \\
\hline $\begin{array}{l}\text { Framing clear } \\
\text { school goals }\end{array}$ & 4.35 & 0.53 & -0.645 & 0.155 & & & & & & & & & & & \\
\hline $\begin{array}{l}\text { Communicating } \\
\text { clear school goals }\end{array}$ & 4.41 & 0.57 & -0.678 & 0.348 & 0.690 & & & & & & & & & & \\
\hline $\begin{array}{l}\text { Coordinating } \\
\text { curriculum }\end{array}$ & 4.27 & 0.52 & -0.423 & 0.180 & 0.692 & 0.722 & & & & & & & & & \\
\hline $\begin{array}{c}\text { Monitoring student } \\
\text { progress }\end{array}$ & 4.23 & 0.57 & -0.364 & 0.211 & 0.586 & 0.727 & 0.741 & & & & & & & & \\
\hline $\begin{array}{l}\text { Protecting } \\
\text { instructional time }\end{array}$ & 4.48 & 0.44 & -0.663 & -0.100 & 0.447 & 0.532 & 0.509 & 0.528 & & & & & & & \\
\hline $\begin{array}{l}\text { Promoting } \\
\text { professional } \\
\text { development }\end{array}$ & 4.35 & 0.50 & -0.199 & -1.00 & 0.491 & 0.608 & 0.615 & 0.648 & 0.585 & & & & & & \\
\hline $\begin{array}{l}\text { Maintaining high } \\
\text { visibility }\end{array}$ & 4.13 & 0.63 & -.299 & -0.675 & 0.467 & 0.619 & 0.544 & 0.630 & 0.560 & 0.604 & & & & & \\
\hline $\begin{array}{l}\text { Providing incentives } \\
\text { for teachers }\end{array}$ & 4.14 & 0.71 & -0.582 & -0.155 & 0.525 & 0.615 & 0.588 & 0.665 & 0.487 & 0.540 & 0.623 & & & & \\
\hline $\begin{array}{l}\text { Providing incentives } \\
\text { for students }\end{array}$ & 4.35 & 0.58 & -0.528 & -0.499 & 0.524 & 0.664 & 0.646 & 0.699 & 0.562 & 0.623 & 0.624 & 0.713 & & & \\
\hline $\begin{array}{l}\text { Knowledge and } \\
\text { understanding }\end{array}$ & 4.14 & 0.42 & 0.250 & -0.283 & 0.237 & 0.353 & 0.364 & 0.362 & 0.271 & 0.4500 . & 0.359 & 325 & 0.368 & & \\
\hline $\begin{array}{l}\text { Teaching and } \\
\text { learning skills }\end{array}$ & 4.19 & 0.42 & 0.180 & -0.389 & 0.272 & 0.361 & 377 & 391 & 0.263 & 0.438 & 0.375 & 0.351 & 0.417 & 0.837 & \\
\hline $\begin{array}{l}\text { Teachers' } \\
\text { professional } \\
\text { development } \\
\text { practices }\end{array}$ & 4.19 & 0.42 & 0.094 & -0.549 & 0.255 & 0.403 & 0.396 & 0.411 & 0.269 & 0.501 & 0.389 & 0.338 & 0.451 & 0.702 & 0.769 \\
\hline
\end{tabular}

Figure 2 shows the interaction model of instructional leadership and the science teaching competency. The findings show that all the dimensions suggested for instructional leadership and the science teaching competency are appropriate when the loading factor exceeds 0.7 . The findings also show that all the fit indexes tested have reached the desired level of validation of the proposed hypothesis model as in the conceptual framework and is consistent with the data collected.

Table 2 shows the critical ratio (CR) of instructional leadership contribution to the science teaching competency above the value of 1.96 . The results indicate the contribution is significant. The results are likewise with instructional leadership dimensions and other science teaching competencies.

Table 3 shows detailed indexes fit and bootstrap values that meet the criteria required to verify that the proposed model corresponds to the data collected.

\section{Discussion}

The findings of this study have successfully developed the model for instructional leadership on the science teaching competency. The findings confirm (Hallinger \& Murphy, 1987) instructional leadership theory which proposed three 


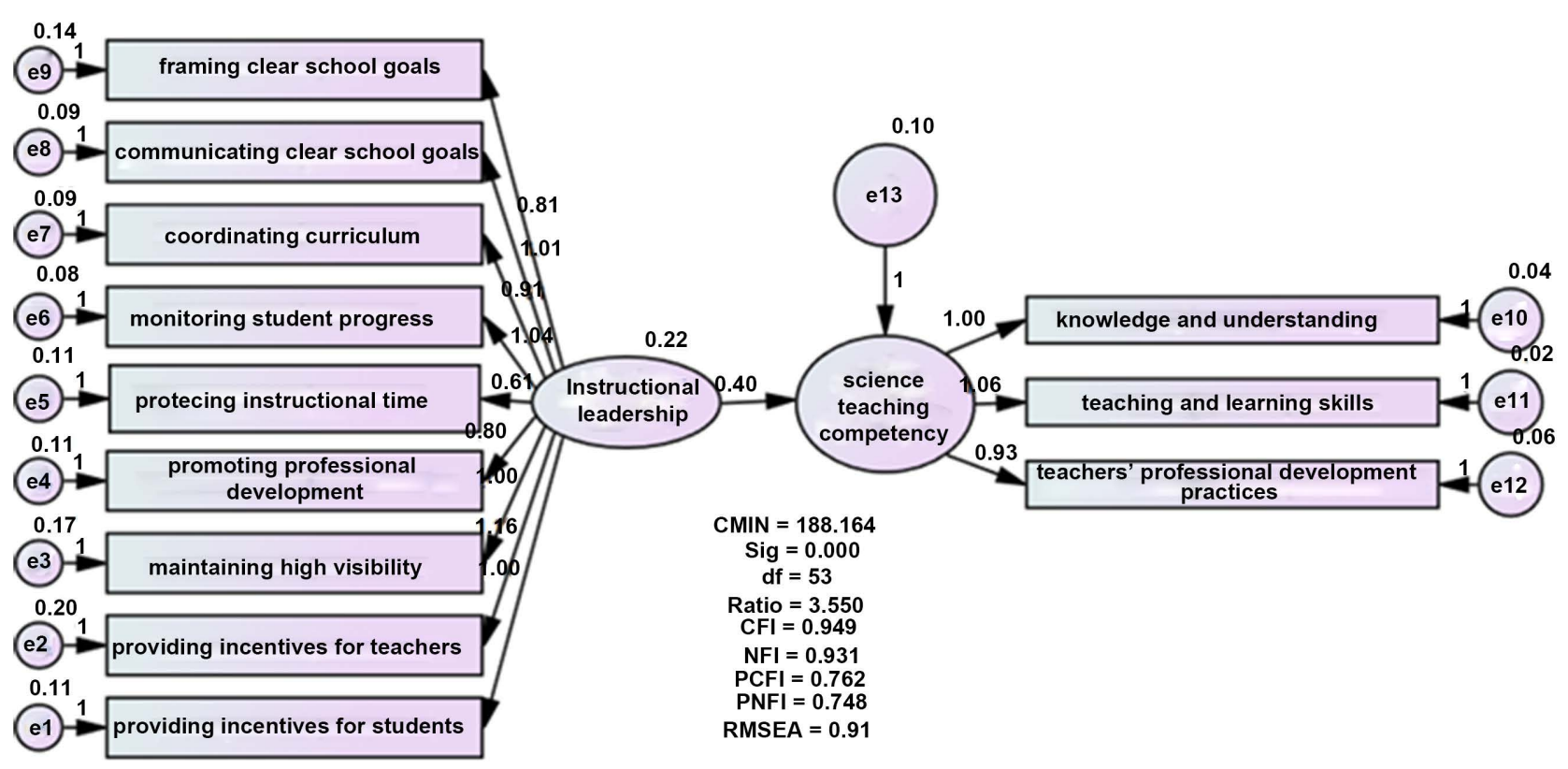

Figure 2. Final model.

Table 2. Regression weights.

\begin{tabular}{|c|c|c|c|c|c|c|c|}
\hline & & & Estimate & S.E. & C.R. & $\mathbf{P}$ & Label \\
\hline Science teaching competency & $<---$ & Instructional_leadership & 0.397 & 0.046 & 8.589 & $* * *$ & par_11 \\
\hline Providing incentives for students & $<---$ & Instructional_leadership & 1.000 & & & & \\
\hline Providing incentives for teachers & $<---$ & Instructional_leadership & 1.160 & 0.074 & 15.731 & $* * *$ & par_1 \\
\hline Maintaining high visibility & $<---$ & Instructional_leadership & 1.001 & 0.067 & 14.960 & $* * *$ & par_2 \\
\hline Promoting professional development & $<---$ & Instructional_leadership & 0.804 & 0.053 & 15.173 & $* * *$ & par_3 \\
\hline Protecting instructional time & $<---$ & Instructional_leadership & 0.612 & 0.049 & 12.605 & $* * *$ & par_4 \\
\hline Monitoring students' progress & $<---$ & Instructional_leadership & 1.035 & 0.057 & 18.198 & $* * *$ & par_5 \\
\hline Coordinating curriculum & $<---$ & Instructional_leadership & 0.908 & 0.053 & 17.037 & $* * *$ & par_6 \\
\hline Communicating clear school goals & $<---$ & Instructional_leadership & 1.012 & 0.058 & 17.542 & $* * *$ & par_7 \\
\hline Framing clear school goals & $<---$ & Instructional_leadership & 0.808 & 0.058 & 13.826 & $* * *$ & par_8 \\
\hline Knowledge and skills & $<---$ & Science teaching competency & 1.000 & & & & \\
\hline Teaching and learning skills & $<---$ & Science teaching competency & 1.064 & 0.045 & 23.539 & $* * *$ & par_9 \\
\hline Teachers' professional development practices & $<---$ & Science teaching competency & 0.931 & 0.050 & 18.508 & $* * *$ & par_10 \\
\hline
\end{tabular}

dimensions of instructional leadership that are defining school goals, managing curriculum and teaching and fostering school climate. The findings also confirmed the proposed teaching leadership function which are framing clear school goals, communicating clear school goals, coordinating curriculum, monitoring student progress, protecting instructional time, promoting professional development, maintaining high visibility, providing incentives for teachers and providing incentives for students. The findings as well confirmed the proposed science teaching competency dimensions which are knowledge and understanding, teaching and learning skills and teachers' professional development practices. 
Table 3. Model Fit.

\begin{tabular}{ccc}
\hline Indexes Fit & Suggested Range & Result \\
\hline$\chi^{2}$ & Small & 188.164 \\
$\mathrm{df}$ & - & 53 \\
$\mathrm{P}$ & $>0.05$ & 0.000 \\
Ratio $\left(\chi^{2} / \mathrm{df}\right)$ & $<5$ & 3.55 \\
GFI & $>0.90$ & 0.906 \\
CFI & $>0.90$ & 0.949 \\
RMSEA & $<0.08$ & 0.091 \\
PCFI & $>0.50$ & 0.762 \\
PNFI & $>0.50$ & 0.748 \\
Boostrap Bollen-Stine & $>0.05$ & 0.531 \\
\hline
\end{tabular}

Furthermore, the study shows that instructional leadership has a positive relationship and contributes significantly to the science teaching competency. The study's findings support (Ibrahim \& Amin, 2014) study which went on to develop the instructional leadership model and teaching competency. Their study of 481 teachers in 55 secondary schools in Terengganu demonstrated a close relationship between instructional leadership and teaching competency. The findings also supported (Yusof \& Ibrahim, 2015) survey results that identify the contributions of virtual instructional leadership to teaching competency. They found that virtual instructional leadership contributed significantly to the teaching competency.

Interestingly, the study's findings are also in line with the findings of Davarajoo (2012) in the study of instructional leadership relationships with work commitment and job satisfaction of teachers in the Kuala Selangor district primary school. He found that there was a significant relationship between instructional leadership and work commitment and teachers' job satisfaction. But the relationship between these two variables is a weak relationship and is most likely due to other factors besides instructional leadership that also influences teaching competency. Equally important, Mohd Yusri (2012) has proven that there is a mediator factor that affects teaching competency which is self-efficacy. Another possibility is that teaching competency here involves teachers of science subjects that differ slightly from teachers of other subjects. Since science teaching involves science process skills that emphasize on inquiry exploration and problem-solving, most principals, not having the science background, may lack this skill to be as effective.

In conclusion, school principals can adopt and practice the instructional leadership functions drawn from this study as a guideline. This allows principals to improve their instructional leadership abilities and influence teachers teaching competency. In addition, the Ministry of Education Malaysia (KPM) and Teachers Training Institutions should emphasize the concept of instructional 
leadership to further strengthen their leadership training modules. It is recommended that the role of school principals be re-evaluated to reduce administrative duties not related to teaching and learning but is re-directed towards instructional leadership. Further, providing science teachers with the opportunity to engage in the latest scientific teaching strategies may benefit eaching competency. Future research is needed on the level of instructional leadership in Malaysia drawn from a sample of all Malaysian principals and teachers.

\section{Conflicts of Interest}

The authors declare no conflicts of interest regarding the publication of this paper.

\section{References}

Airasian, P., \& Gay, L. R. (2003). Educational Research: Competencies for Analysis and Applications (7th ed.). Upper Saddle River, NJ: Pearson Education.

Bhargava, A., \& Pathy, M. (2011). Perception of Student Teachers about Teaching Competencies. American International Journal of Contemporary Research, 1, 77-81. http://aijcrnet.com/journals/Vol._1_No.1_July_2011/10.pdf

Blase, J., \& Blase, J. (2000). Effective Instructional Leadership: Teachers' Perspectives on How Principals Promote Teaching and Learning in Schools. Journal of Educational Administration, 38, 130-141. https://doi.org/10.1108/09578230010320082

Bollen, K. A., \& Stine, R. (1992). Bootstrapping Goodness of Fit Measures in Structural Equation Models. Sociological Methods and Research, 21, 205-229. https://doi.org/10.1177/0049124192021002004

Byrne, B. M. (1998). Structural Equation Modeling with LISREL, PRELIS and SIMPLIS: Basic Concepts, Applications and Programming. Mahwah, NJ: Erlbaum.

Cohen, L., Manion, L., \& Morrison, K. (2007). Research Methods in Education (6th ed.). New York, NY: Routledge Taylor \& Francis Group. https://doi.org/10.4324/9780203029053

Davarajoo, E. (2012). Hubungan Antara Kepimpinan Pengajaran Guru Besar Dengan Komitmen Kerja Dan Kepuasan Kerja Guru Sekolah Rendah Di Zon Tanjung Karang. Kepemimpinan Untuk Pembelajaran (Leadership for Learning).

Day, C., Gu, Q., \& Sammons, P. (2016). The Impact of Leadership on Student Outcomes: How Successful School Leaders Use Transformational and Instructional Strategies to Make a Difference. Educational Administration Quarterly, 52, 221-258. https://doi.org/10.1177/0013161X15616863

Guru, B. P. (2009). Standard Guru Malaysia (pp. 1-187).

Hallinger, P. (2005). Instructional Leadership and the School Principal: A Passing Fancy that Refuses to Fade Away. Leadership and Policy in Schools, 4, 221-239. https://doi.org/10.1080/15700760500244793

Hallinger, P. (2009). Leadership for 21st Century Schools : From Instructional Leadership to Leadership for Learning. Hong Kong: Chair Professors Public Lecture Series of the Hong Kong Institute of Education, hlm. 32.

Hallinger, P., \& Murphy, J. F. (1985). Assessing the Instructional Management Behavior of Principals. Elementary School Journal, 86, 217-247. https://doi.org/10.1086/461445

Hallinger, P., \& Murphy, J. F. (1987). Assesing and Developping Principal Instructional 
Leadership. Educational Leadership, 45, 54-61.

Hallinger, P., Wang, W. C., Chen, C. W., \& Li, D. (2015). Assessing Instructional Leadership with the Principal Instructional Management Rating Scale (pp. 1-204). Berlin: Springer. https://doi.org/10.1007/978-3-319-15533-3

Ibrahim, M. Y., \& Amin, A. (2014). Model Kepemimpinan Pengajaran Pengetua dan Kompetensi Pengajaran Guru. Jurnal Kurikulum \& Pengajaran Asia Pasifik, 2, 11-25.

Khan, Z., Khan, U. A., Shah, R. U., \& Iqbal, J. (2009). Instructional Leadership, Supervision and Teacher Development. Dialogue, 4, 580-592.

http://search.ebscohost.com/login.aspx?direct=true\&db=a9h\&AN=57631231\&site=eho $\underline{\text { st-live }}$

Knight, G. P., Virdin, L. M., Ocampo, K. A., \& Roosa, M. (1998). An Examination of the Cross-Ethnic Equivalence of Measures of Negative Life Events and Mental Health among Hispanic and Anglo-American Children. American Journal of Community Psychology, 22, 767-783. https://doi.org/10.1007/BF02521558

Krejcie, R. V., \& Morgan, D. W. (1970). Determining Sample Size for Research Activities. Educational and Psychological Measurement, 30, 607-610.

https://doi.org/10.1177/001316447003000308

Kunter, M., Klusmann, U., Baumert, J., Richter, D., Voss, T., \& Hachfeld, A. (2013). Professional Competence of Teachers: Effects on Instructional Quality and Student Development. Journal of Educational Psychology, 105, 805-820. https://doi.org/10.1037/a0032583

Leithwood, K., Harris, A., \& Hopkins, D. (2008). Seven Strong Claims about Successful School Leadership. School Leadership \& Management, 28, 27-42. https://doi.org/10.1080/13632430701800060

Liakopoulou, M. (2011). The Professional Competence of Teachers : Which Qualities, Attitudes, Skills and Knowledge Contribute to a Teacher's Effectiveness? International Journal of Humanities and Social Science, 1, 66-78.

Mansor, A. N. (2006). Amalan Pengurusan Pengetua Sekolah Menengah: Satu Kajian Kes. Tesis Doktor Falsafah, Bandar Baru Bangi: UKM.

Mariani, A., \& Ismail, Z. (2013). Pengaruh Kompetensi Guru Matematik Ke Atas Amalan Pengajaran Kreatif.

Marks, H. M., \& Printy, S. M. (2003). Principal Leadership and School Performance : An Integration of Transformational and Instructional Leadership (pp. 370-397). Hong Kong: The Hong Kong Institute of Education.

Mattar, D., Pansiri, N. O., Heck, R. H., Shatzer, R. H., Caldarella, P., Hallam, P. R., Brown, B. L., et al. (2013). Principals' Instructional Leadership and School Performance: Implications for Policy Development. Journal of Educational Administration, 48, 130-141.

Meyers, L. S., Gamst, G., \& Guarino, A. J. (2006). Applied Multivariate Research: Design and Interpretation. London: Sage.

Ministry of Education (2013). Laporan Jemaah Nazir. Inspectorate and Quality Assurance (JNJK). Putrajaya: Ministry of Education, Malaysia.

Mohd Yusri, I. (2012). Model Kepimpinan Pengajaran Pengetua Efikasi dan Kompetensi Pengajaran. Universiti Malaysia Terengganu.

Nasri, N. M. (2010). Standard Guru Sains Malaysia: Kerangka Awal. Tesis Sarjana, Universiti Kebangsaan Malaysia.

Piaw, C. Y. (2009). Asas Statistik Penyelidikan: Analisis Data Skala Ordinal dan Skala Nominal. Shah Alam: McGraw-Hill. 
Quinn, D. M. (2002). The Impact of Principal Leadership Behaviors on Instructional Practice and Student Engagement. Journal of Educational Administration, 40, 447-467. https://doi.org/10.1108/09578230210440294

Sahin, S. (2011). Relationship between Instructional Leadership Style and School Culture. Educational Sciences: Theory \& Practice, 11, 1920-1927.

Yusof, M. R., \& Ibrahim, M. Y. (2015). Sumbangan Kepimpinan Instruksional Maya Terhadap Kompetensi Pengajaran Guru. In Proceeding of the International Conference and Social Science Research (pp.756-765). Lumpur: Melia hotel Kuala. 